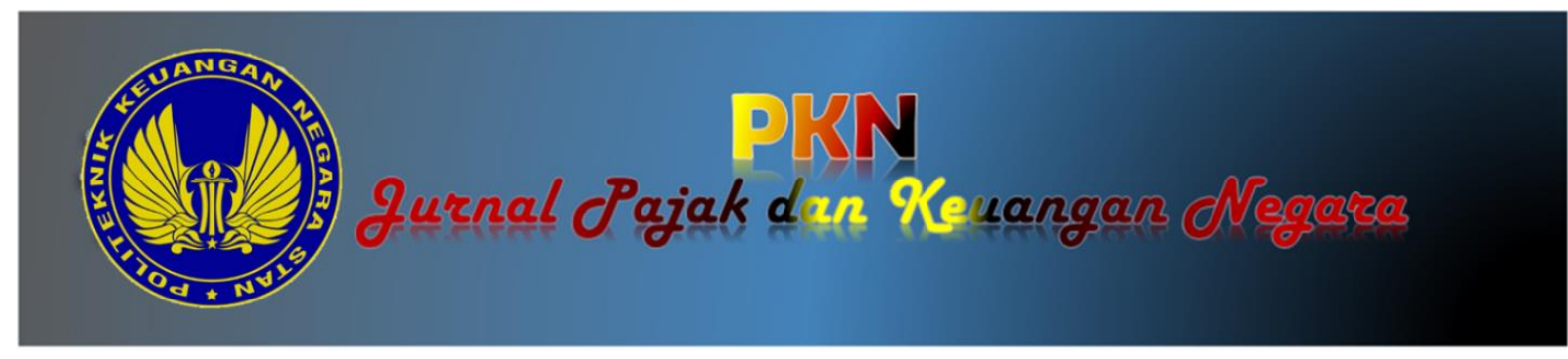

\title{
IMPLEMENTASI INSENTIF PAJAK MENURUT MODEL G EDWARD III
}

\author{
I Gede Komang Chahya Bayu Anta Kusuma, \\ Politeknik Keuangan Negara STAN \\ Yoan Theo Samuel Simanungkalit, \\ Direktorat Jenderal Pajak
}

Alamat Korespondensi: igbayuantakusuma@pknstan.ac.id

INFORMASI ARTIKEL

Diterima Pertama

[23022022]

Dinyatakan Diterima

[22032022]

KATA KUNCI:

Insentif pajak, angsuran PPh pasal 25, kebijakan fiskal

\section{KLASIFIKASI JEL:}

E620

\begin{abstract}
The government issues a National Economic Recovery (PEN) policy which is tax incentives. This study aims to determine implementation of tax incentives in reducing the current payment income tax article 25 for corporate taxpayers at KPP Pratama Medan Petisah through the $G$ Edward III model and administration constraint in the implementation of this policy. This research uses qualitative approaches that focuses on the implementation of tax incentives and administration contraints. This study involved tax official interviews who helds with the implementation of tax incentive policies. The study reveals that the implementation of tax incentives to reducing the current payment income tax article 25 was submitted by taxpayers in April 2020 but decrease to zero in December 2020. secondly this research highlights the contraint of taxpayers such as using unfamiliar applications forms, complicated administration and the uncertainty perception of incentives policy. The $G$ Edward III model about success factor for implementing in tax incentive policy was ineffective because of the communication and disposition factor. However, other factors such as resources and bureaucratic structure are good enough and support the implementation of tax incentives.
\end{abstract}

\section{ABSTRAK}

Kebijakan Pemulihan Ekonomi Nasional (PEN) salah satunya berupa insentif pajak. Penelitian ini bertujuan untuk mengetahui keberhasilan insentif pajak berupa pengurangan angsuran PPh pasal 25 bagi wajib pajak Badan di KPP Pratama Medan Petisah melalui model G Edward III dan identifikasi kendala dalam implementasi insentif pajak. Penelitian menerapkan metode kualitatif yang berfokus pada keberhasilan penerapan insentif pajak dan kendala yang dihadapi dengan mengumpulkan informasi melalui wawancara dengan pihak yang melaksanakan kebijakan insentif pajak. Hasil penelitian menemukan bahwa implementasi insentif pajak berupa pengurangan angsuran PPh pasal 25 hanya dimanfaatkan oleh wajib pajak pada bulan April 2020. Pada bulan selanjutnya pemanfaatan insentif ini terus menurun bahkan nihil di bulan Desember 2020. Adanya kendala penggunaan teknologi berupa aplikasi yang belum dipahami, administrasi yang diaanggap rumit dan persepsi wajib pajak kurang tepat mengenai insentif pajak sehingga memutuskan tidak memanfaatkan insentif tersebut. Bila dikaitkan dengan model G Edward III kebijakan insentif pajak ini belum berhasil karena unsur komunikasi dan disposisi yang belum efektif. Namun untuk faktor lainnya berupa sumber daya dan sturktur birokrasi sudah cukup baik dan mendukung penerapan insentif pajak. 


\section{PENDAHULUAN}

Indonesia menerapkan Pembatasan Sosial Berskala Besar (PSBB) untuk mengatasi pandemi virus covid-19. Kondisi ini mengakibatkan perekonomian tersendat bahkan berhenti. Pada kuartal III tahun 2020 Indonesia mengalami pertumbuhan ekonomi negatif karena meningkatnya angka pengangguran, penurunan daya beli masyarakat. Menurut Fauzia (2020), Indonesia sendiri mengalami resesi hingga 3,49\% pada kuartal III tahun 2020. Kondisi ini tentunya akan berdampak pada penerimaan pajak yaitu pada semester I tahun 2020 hanya mencapai Rp 513,65 triliun atau sebesar $44,02 \%$ dari target penerimaan pajak tahun 2020 atau turun $15 \%$ dari tahun sebelumnya Rp 604,3 triliun.

Pemerintah menerbitkan Peraturan Pemerintah Nomor 23 tahun 2020 tentang Pelaksanaan Pemulihan Ekonomi Nasional (PEN) sebagai upaya melindungi, mempertahankan dan meningkatkan kemampuan ekonomi dan keberlangsungan usaha. Program PEN ini memberikan berupa bantuan sosial dan bantuan untuk kegiatan usaha, salah satunya berupa pengurangan angsuran PPh pasal 25 bagi wajib pajak.

Fasilitas insentif pajak kepada wajib pajak diterapkan dalam upaya mendorong kepatuhan wajib pajak dan meningkatkan penerimaan pajak. Contohnya insentif kepada Usaha Mikro Kecil Menengah (UMKM), bertujuan untuk memberikan kemudahan kepada wajib pajak UMKM dalam menghitung, menyetor dan melaporkan PPh dapat meningkatkan kepatuhan wajib pajak UMKM di Jakarta Selatan khususnya kewajiban administrasi perpajakan (Rachmawati, 2016). Insentif pajak juga menambah tingkat kepatuhan dan meningkatkan setoran pajak dari sektor UMKM (Khairiyah, 2019). Hasil yang sama juga ditemukan dalam penelitian di wilayah KPP Pratama Makasar Selatan menghasilkan pengaruh positif insentif pajak pada tingkat kepatuhan wajib pajak (Latief, 2020).

Pemberian insentif pajak lainnya berupa penurunan tarif pajak dalam revaluasi aset. Insentif ini dimanfaatkan $16 \%$ dari total emiten di pasar modal. Penelitian ini menemukan kebijakan revaluasi aset masih diminati wajib pajak badan dan dapat meningkatkan penerimaan pajak (Ahmar et al, 2018). Hasil penelitian lain menunjukkan insentif pajak atas revaluasi aset tidak berpengaruh negatif terhadap nilai perusahaan dan jangka waktu pelaksanan insentif yang terlalu pendek menyebabkan insentif tidak dimanfaatkan secara optimal oleh wajib pajak (Muawanah \& Kurniawan, 2018). Kebijakan insentif pajak atas revaluasi aset bertujuan untuk mendorong investasi dan meningkatkan kinerja perusahaan sehingga dapat meningkatkan penerimaan pajak. Namun hasil penelitian menunjukkan insentif tidak banyak dimanfaatkan dan revaluasi aset suatu perusahaan tidak secara langsung meningkatkan kinerja perusahaan (Butar, 2019).

Pada tahun 2016, pemerintah menerbitkan insentif pajak melalui program tax amnesty. Program ini dimanfaatkan $35,1 \%$ wajib pajak yang terdaftar di perusahaan masuk bursa sehingga dapat menambah penerimaan pajak (Suratno, 2020). Hasil penelitian di wilayah Batam, menemukan bahwa insentif pajak dalam tax amnesty meningkatkan kepatuhan wajib pajak badan (Kartikaningdyah, 2018). Di KPP Madya Makasar, faktor pengetahuan, persepsi, pelayanan fiskus dan sanksi administrasi secara simultan mempengaruhi program tax amnesty (Asrul, 2018). Penelitian lain juga menemukan bahwa Insentif pajak pada program tax amnesty dapat menambah tingkat kepatuhan pajak dalam jangka pendek, tetapi belum memperoleh data pembanding untuk jangka panjang (Murweni, 2018).

Berdasarkan beberapa bentuk insentif pajak yang pernah diterapkan di Indonesia, hasil penelitian menunjukkan hasil yang belum optimal. Hal ini mengindikasikan kebijakan publik berupa insentif pajak yang diputuskan pemerintah belum menjamin keberhasilan suatu kebijakan. Keberhasilan implementasi kebijakan publik dipengaruhi oleh beberapa variabel yang bersifat individual, kelompok atau institusi. Insentif pajak merupakan usaha pemerintah untuk menambah penerimaan pajak dan sarana untuk menggerakkan perekonomian dengan membantu investor untuk mengembangkan kegiatan usaha. Pada masa pandemi, insentif pajak yang diputuskan pemerintah bertujuan untuk membantu wajib pajak menjaga likuiditas perusahaan sehingga dapat bertaham melewati krisis perekonomian.

Model G Edward III merupakan unsur yang mempengaruhi pelaksanaan kebijakan publik meliputi empat unsur utama yaitu komunikasi, sumberdaya, disposisi serta struktur birokrasi (Winarno, 2014). Dalam penelitian ini, model G Edward III akan digunakan untuk mengukur keberhasilan pelayanan Insentif pajak yaitu fasilitas penurunan angsuran PPh pasal 25 dan permasalahan yang timbul dalam penerapannya.

Penelitian dengan model ini sudah pernah dilakukan dengan obyek insentif yang berbeda yaitu terkait PPh final yang ditanggung pemerintah. Hasil penelitian menemukan bahwa insentif pajak di KPP Pratama Pontianak Timur hanya dimanfaatkan oleh 28,23\% dari jumlah wajib pajak terdaftar karena kurang efektifnya komunikasi dan sumber daya dalam pelaksanaan insentif pajak (Arifani \& Anta, 2021). Penelitian tentang kebijakan pemberlakuan pajak progresif kendaraan bermotor di Samsat Medan Selatan menemukan faktor komunikasi, sumber daya manusia, disposisi serta birokrasi telah diterapkan secara baik dan hasilnya dapat memberikan kemudahan dalam layanan pajak progresif kepada 
masyarakat (Sinulingga et al, 2018).

Selanjutnya penelitian model G Edward III dalam penerapan Undang-Undang Nomor 6 Tahun 2004 tentang Desa di Landungsari menunjukkan hasil yang baik karena pola komunikasi yang baik, sumber daya yang mendukung, sikap aparatur desa yang berkomitmen dan bertangungjawab dalam melaksanakan program dana desa, meskipun partisipasi masyarakatnya masih rendah (Setyawan \& Srihardjono, 2016). Di Surabaya, model yang sama juga diterapkan dalam penelitian atas pemungutan Pajak Bumi dan Bangunan (PBB) yang belum optimal karena rendahnya faktor komunikasi, keterbatasan sumber daya manusia, disposisi yang belum dapat merespon permasalahan secara cepat dan struktur birokrasi yang tidak jelas karena belum tersedia standard operating procedure (Wulan, 2015).

Dalam penelitian sebelumnya, Model G Edward III diterapkan dalam penelitian atas kebijakan publik yang diputuskan pemerintah. Demikian juga kebijakan di bidang perpajakan, sebagai bagian kebijakan publik diharapkan dapat mencapai hasil optimal, berupa capaian penerimaan pajak sesuai target atau terpenuhinya tingkat kepatuhan yang ditetapkan.

Berdasarkan uraian di atas, Penelitian ini bertujuan untuk mengetahui keberhasilan implementasi kebijakan insentif pajak dan kendala dalam implementasi insentif PPh pasal 25 di KPP Pratama Medan Petisah berpedoman pada faktor keberhasilan kebijakan publik menurut teori George Edwards III.

\section{KERANGKA TEORI}

\subsection{Kebijakan Publik}

Kebijakan publik sebagai ilmu administrasi, menggambarkan keputusan pemerintah untuk setiap aktivitas untuk mencapai suatu tujuan tertentu. Katagori kebijakan publik menurut Amir Santoso meliputi tindakan pemerintah dengan tujuan dan maksud tertentu dan dampaknya dapat diramalkan (Winarno, 2014). Penjelasan Thomas Dye (1981) tentang kebijakan publik sebagai pilihan pemerintah dalam melakukan atau tidak melakukan suatu kegiatan dalam mencarikan solusi permasalahan publik (Subarsono, 2020).

Tujuan kebijakan publik, menurut Hallsworth, Parker dan Rutter (2011) terdiri dari dua tahap, pertama langkah formulasi masalah yaitu mengumpulkan masalah yang terjadi, identifikasi faktor penyebab dan peran pemerintah untuk mencarikan alternatif penyelesaian. Kedua, langkah penetapan kebijakan yaitu langkah pemerintah untuk mengelompokkan dan melakukan analisis atas informasi dan pilihan penyelesaian atas permasalahan sehingga pilihan terbaik atas kebijakan dapat diputuskan serta diterapkan (Widyaningtyas, 2020).

Di Indonesia, kebijakan pubik diatur pada Peraturan Menteri Negara Pendayagunaan Aparatur Negara (PAN) Nomor PER/04/M.PAN/4/2007, menjelaskan kebijakan publik merupakan keputusan pemerintah atau lembaga pemerintahan dalam mengatasi permasalahan, untuk melaksanakan kegiatan, atau mewujudkan suatu tujuan yang berkaitan dengan kepentingan serta manfaat untuk orang banyak. Berdasarkan penjelasan di atas, maka langkah pemerintah di bidang perpajakan dalam upaya mencapai target pajak adalah bagian dari kebijakan publik.

\subsection{Model Implementasi Kebijakan Publik}

Menurut Merilee S. Grindle dalam Tachjan (2006) terdapat faktor yang berpengaruh pada capaian kebijakan publik meliputi derajat implementability suatu kebijakan berupa content dan context. Content dan context ini menjelaskan bagian isi dan manfaat dari kebijakan publik yang diterima oleh kelompok masyarakat. Selain itu dijelaskan juga mengenai pedoman rinci pelaksanaan dan dukungan sumber daya yang sesuai kebutuhan. Pendapat lain disampaikan model Warwick (1979) menjelaskan unsur yang mempengaruhi kebijakan publik yakni keterkaitan unsur perencanaan dan implementasi yang saling terkait sehingga perlu memahami permasalahan secara seksama. Dalam penelitian ini akan membahas kebijakan insentif pajak dari model George Edwards III, berupa ukuran efektifitas kebijakan publik dari empat unsur yang memengaruhi yaitu: struktur birokrasi, sumber daya, disposisi dan komunikasi. Unsur-unsur ini melekat pada organisasi yang saling berinteraksi dan berdampak pada pelaksanaan kebijakan secara langsung maupun tidak langsung terhadap keberhasilan kebijakan publik. Unsur organisasi terdiri dari unsur birokrasi, sumber daya, disposisi dan faktor komunikasi merupakan langkah yang harus dilakukan dalam penerapan kebijakan publik (Subarsono, 2020).

Keberhasilan kebijakan publik menurut George Edwards III dipengaruhi oleh (Winarno, 2014):

\subsubsection{Komunikasi}

Komunikasi sebagai salah satu unsur penting dalam keberhasilan implementasi kebijakan publik. Unsur komunikasi pada organisasi dilakukan dengan menjelaskan maksud dan sasaran kebijakan publik secara rinci sehingga rencana dan penerapan kebijakan dapat dioptimalkan. Setiap kebijakan publik tentunya akan ada pihak yang tidak sejalan dan perlu diantisipasi atau pihak yang resisten terhadap kebijakan yang dipilih. Dengan demikian unsur komunikasi diharapkan dapat membentuk pemahaman yang sama untuk 
meningkatkan kinerja dan melaksanakan kebijakan publik yang sudah diputuskan.

Gambar 1. Faktor Implementasi Kebijakan Publik

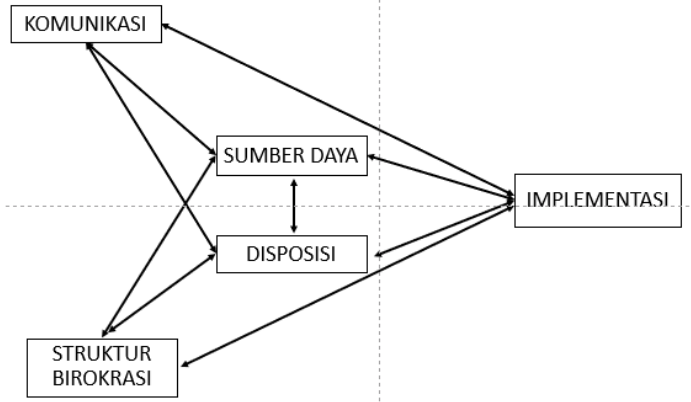

Sumber: Analisis Kebijakan Publik, (Subarsono 2020)

\subsubsection{Sumber Daya}

Dalam melaksanakan kebijakan publik yang dipilih pemerintah perlu dukungan sumber daya yang memadai. Sumber daya dapat berupa tugas dan fungsi, kewenangan, pegawai (personel), keuangan, informasi serta sarana dan prasarana antara lain: gedung, peralatan, lahan dan perlengkapannya.

\subsubsection{Disposisi atau sikap pelaksana}

Dalam melaksanakan kebijakan publik juga dipengaruhi sikap serta komitmen pihak yang melaksanakan kebijakan yaitu pegawai yang melaksanakan, yang ditunjukkan oleh pemahaman atas langkah-langkah yang dikerjakan dan mempunyai kemampuan untuk mengerjakan serta kesamaan pemahaman dalam penerapan kebijakan publik.

Jadi unsur sikap pelaksana dalam implementasi kebijakan diharapkan mampu dilaksanakan sejak tahap awal pelayanan, ketersediaan peraturan dan penegakan hukum.

\subsubsection{Struktur Birokrasi}

Kebijakan publik dapat dilaksanakan apabila ada kewenangan yang diberikan kepada pelaksana, oleh karena itu perlu adanya struktur birokrasi yang rinci pada organisasi. Dalam struktur organisasi yang menjadi pelaksana kebijakan publik harus dilengkapi dengan standard operating prosedure (SOP) secara rinci dan dapat dilaksanakan. SOP ini digunakan sebagai pedoman bagi organisasi maupun bagi masyarakat untuk mengukur penerapan kebijakan yang dipilih. Selain itu SOP juga perlu mempertimbangkan tingkat kemudahan dan kesederhanaan administrasi sehingga dapat diterapkan secara efektif dan efisien.

\subsection{Pembayaran Pajak Tahun Berjalan}

Adam Smith pada four maxims mengenalkan empat asas pemungutan pajak yaitu equity, certainty, convenience dan economy. (Rosdiana, 2005) Asas convenience (kenyamanan) dalam pemungutan pajak menjadi salah satu faktor yang menentukan untuk mewujudkan kemudahan administrasi perpajakan (Rosdiana, 2005). Asas convenience ini menekankan bahwa pajak hendaknya dapat dibayar pada kondisi yang menyenangkan/memudahkan dan tidak memberatkan bagi wajib pajak.

Pembayaran pendahuluan pajak menurut Burns dan krever (1998) menjelaskan bahwa pajak terutang wajib dibayar pada saat yang sudah ditentukan dan jumlah beban pajak yang sebenarnya terutang akan dihitung pada akhir tahun (Setiabudi, 2019). Pembayaran pajak tahun berjalan/pajak pendahuluan menurut Kelley dan Oldman (1973) akan meningkatkan kepatuhan serta efisiensi administrasi perpajakan (Setiabudi, 2019).

Dalam UU PPh, salah satu bentuk pembayaran pajak tahun berjalan adalah pembayaran PPh pasal 25 . Dalam ketentuan ini wajib pajak diminta untuk membayar angsuran PPh pasal 25 berdasarkan jumlah Pajak Penghasilan terhutang pada tahun pajak sebelumnya. Pembayaran PPh pasal 25 setiap bulan ini diharapkan dapat membantu meringankan beban pajak pada akhir tahun dan bagi pemerintah dapat digunakan untuk membiayai pembanguan dan operasional pemerintahan. Menurut Thuronyi (1996) cara untuk menentukan besarnya pajak yang dibayar pada tahun berjalan dapat dilakukan menggunakan jumlah penghasilan kena pajak tahun sebelumnya atau data tahun berjalan dengan estimasi jumlah pajak yang akan terutang (Setiabudi, 2019).

Ketentuan pembayaran angsuran PPh diatur pada pasal 25 UU PPh yang menjelaskan bahwa besarnya angsuran pajak dalam tahun berjalan dihitung dengan jumlah PPh menurut SPT dikurangi jumlah pajak yang dipotong /dipungut pihak ketiga (meliputi jenis PPh pasal 22 dan PPh pasal 23) serta pajak yang dibayar di luar negeri (PPh pasal 24) dibagi dengan dua belas atau jumlah tertentu dalam bagian tahun pajak.

Perhitungan besarnya angsuran Pajak Penghasilan pasal 25 tahun berjalan, melalui Peraturan menteri Keuangan dapat berbeda dalam kondisi tertentu dari wajib pajak yaitu:

a. Wajib pajak masih mempunyai kompensasi kerugian fiskal tahun sebelumnya

b. Wajib pajak yang memperoleh penghasilan yang bersifat tidak teratur

c. Wajib pajak yang menyampaikan SPT Tahunan PPh setelah batas waktu yang ditentukan.

d. Wajib pajak menyampaikan surat perpanjangan batas waktu pelaporan SPT Tahunan PPh.

e. Wajib pajak melakukan pembetulan SPT mengakibatkan meningkatnya jumlah angsuran.

f. Adanya perubahan kondisi usaha dari wajib pajak.

g. Perhitungan angsuran pajak untuk wajib pajak baru;

h. Wajib pajak yang bergerak di bidang perbankan, BUMN/BUMD, wajib pajak yang terdaftar di bursa efek, dan wajib pajak lainnya yang menyusun 
laporan keuangan secara berkala.

Dengan adanya pembayaran angsuran pajak ini, diharapkan jumlah kekurangan pajak yang dibayar pada akhir tahun akan lebih ringan dan memberikan kenyamanan beban keuangan bagi wajib pajak.

Gambar 2. Skema Perhitungan Angsuran PPh pasal 25

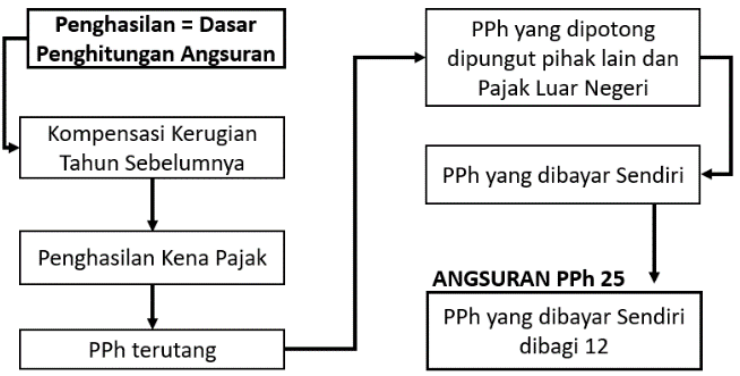

Sumber: Diolah penulis

\subsection{Insentif pajak}

Pada Cambridge Dictionary, Insentif pajak merupakan ketentuan perpajakan khusus yang umumnya berpengaruh pada jumlah pajak yang lebih kecil dari seharusnya dibayarkan ke kas negara, dan diterbitkan oleh pemerintah untuk mendorong perekonomian negara (Kartiko, 2020).

Menurut United Nations Conference on Trade and development (UNTAD) (Khairiyah, 2019) insentif adalah keuntungan terukur yang ditujukan kepada perusahaan atau perusahaan dengan kriteria tertentu oleh pemerintah untuk mendorong perusahaan berperilaku sesuai cara tertentu, termasuk langkahlangkah yang direncanakan secara khusus untuk meningkatkan jumlah pengembalian dari usaha Foreign Direct Investment (FDI) untuk jenis tertentu atau efisiensi biaya dan risiko yang lebih rendah.

Dalam program Pemulihan Ekonomi Nasional (PEN) Pemerintah memutuskan beberapa fasilitas dalam bidang perpajakan. Salah satu fasilitas untuk wajib pajak adalah pengurangan jumlah angsuran PPh pasal 25 bagi wajib pajak terdampak pandemi Covid-19. Prosedur untuk memanfaatkan fasilitas insentif ini diatur pada Peraturan Menteri Keuangan Nomor PMK44/PMK.03/2020, PMK-86/PMK.03/2020 dan terakhir PMK-110/PMK.03/2020. Ketentuan ini menjelaskan bentuk insentif yang dapat dimanfaatkan wajib pajak berupa pajak ditanggung pemerintah untuk jenis PPh pasal 21, tidak membayar PPh pasal 22 atas kegiatan impor, PPh final untuk UMKM yang ditanggung pemerintah, penurunan angsuran PPh pasal 25 serta proses pengembalian Pajak Pertambahan Nilai (PPN). Insentif dalam bentuk penurunan jumlah angsuran PPh pasal 25 dapat turun sampai dengan $50 \%$ dari angsuran sebelumnya dan dapat dimanfaatkan oleh wajib pajak yang memenuhi kriteria. Kriteria wajib pajak ini meliputi:

a. Wajib pajak wajib memenuhi Klasifikasi Lapangan Usaha (KLU) yang ditentukan pada lampiran
Peraturan Menteri Keuangan ini.

b. Kelompok wajib pajak yang termasuk perusahaan mendapat Kemudahan Impor Tujuan Ekspor (KITE).

c. Wajib pajak telah berstatus sebagai penyelenggara dan/atau pengusaha Kawasan Berikat ataupun pengusaha di Kawasan Berikat (PDKB)

Wajib pajak yang memenuhi kriteria di atas, dapat memperoleh insentif apabila sudah memenuhi kelengkapan prosedur administrasi yaitu:

a. Menyampaikan surat permohonan tertulis ke KPP melalui situs www.pajak.go.id

b. Wajib pajak menerima surat persetujuan atau penolakan surat pemberitahuan

c. Wajib pajak yang permohonannya disetujui wajib melaporkan realisasi pengurangan angsuran PPh pasal 25 setiap masa pajak untuk masa pajak sampai Desember. Laporan realisasi disampaikan paling lambat pada tanggal 20 bulan berikutnya setelah berakhirnya masa pajak yang dilaporkan.

2.5. Insentif Pajak berupa pengurangan angsuran PPh pasal 25

Dalam keadaan pandemi pemerintah memutuskan program Pemulihan Ekonomi Nasional (PEN), salah satunya dalam bentuk fasilitas pajak yakni pengurangan angsuran PPh pasal 25. Kondisi pandemi yang berdampak luas mengakibatkan terus dipantau sehingga jenis usaha yang menerima insentif terus diperluas.

Gambar 3. Skema Pengurangan Angsuran PPh pasal 25

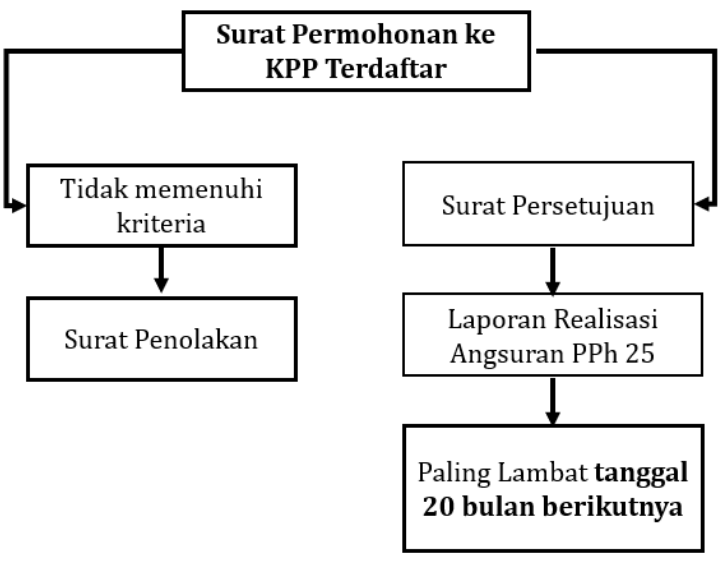

Sumber: Diolah penulis

Hal ini terbukti dengan beberapa kali perubahan Peraturan Menteri Keuangan (PMK) terkait Insentif pajak yaitu PMK-44/PMK.03/2020, diubah dengan PMK-86/ PMK.03/2020 dan terakhir diubah dengan PMK No. 110/PMK.03/2020. Perubahan yang terjadi pada peraturan menteri keuangan ini meliputi ditambahnya jenis Klasifikasi Lapangan Usaha (KLU) yang menerima insentif dan bertambahnya nilai penurunan angsuran pajak PPh pasal 25 sampai dengan 
$50 \%$ dari seharusnya dibayar wajib pajak. Prosedur yang diatur dalam PMK meliputi:

a. Wajib pajak penerima insentif mempunyai KLU yang tercantum dalam lampiran PMK.

b. Kelompok Wajib pajak yang termasuk penerima fasilitas Kemudahan Impor Tujuan Ekspor (KITE)

c. Kelompok wajib pajak yang berstatus sebagai penyelenggara dan/atau pengusaha kawasan berikat ataupun pengusaha di Kawasan Berikat (PDKB).

d. Besarnya penurunan angsuran PPh pasal 25 mencapai paling tinggi $50 \%$ dari jumlah yang tercantum pada SPT Tahunan PPh.

Wajib pajak yang ingin memanfaatkan insentif pajak wajib mengajukan pemohonan secara tertulis ke Kantor Pelayanan Pajak terdaftar. Atas permohonan tersebut akan dilakukan penelitian dan pengecekan kelengkapan persyaratan, apabila permohonan wajib pajak sudah memenuhi syarat maka KPP akan memberikan surat keterangan (Sket). Berdasarkan sket tersebut wajib pajak selanjutnya melaporkan realisasi insentif pajak paling lambat pada tanggal 20 bulan berikutnya. Dalam masa pandemi seluruh layanan insentif yang diberikan oleh KPP dilakukan secara online sehingga wajib pajak dapat mengajukan insentif dari mana saja.

\subsection{Penelitian terdahulu}

Penerapan insentif pajak diberikan dalam upaya meningkatkan kepatuhan pajak. Penerapan penghitungan setoran PPh pasal 25 bagi UMKM yang terdampak covid-19 telah dilakukan dengan studi kasus CV RM dengan hasil KLU wajib pajak termasuk KLU yang terdampak covid-19 sehingga diberikan penurunan setoran PPh pasal 25 (Hafidiah, 2021). Penelitian terkait insentif juga dilakukan terhadap UMKM Tenun di Jepara, hasilnya menunjukkan bahwa pemberian insentif pajak berdampak positif pada kelangsungan usaha (Budiman, 2020). Riset-riset sebelumnya tidak banyak membahas bagaimana keberhasilan dari penerapan Insentif, dan apakah pemberian insentif merupakan kebijakan yang tepat. Oleh karena itu, penelitian ini akan membahas bagaimana implementasi fasilitas insentif pajak melalui pendekatan G Edward III.

\section{METODE PENELITIAN}

Penelitian mengenai insentif pajak ini disusun dengan metode kualitatif. Denzin dan Lincoln (1994) dalam Herdiansyah, menjelaskan penelitian kualitatif bertujuan untuk memahami secara mendalam tentang organisasi atau peristiwa khusus (Herdinsyah, 2019). Penelitian diharapkan dapat memperoleh pemahaman yang mendasar oleh peneliti karena peneliti berproses dan menyatu menjadi bagian dari subyek dan latar yang akan diteliti (Herdinsyah, 2019). Sedangkan menurut Creswell, Penelitian kualitatif adalah penelitian yang bertujuan memahami permasalahan manusia dibidang sosial dengan memberikan gambaran terperinci dari sumber informasi dan dilakukan tanpa adanya keterlibatan dari peneliti (Herdinsyah, 2019). Metode ini digunakan berdasarkan ciri dari metode kualitatif yang disampaikan Creswell, Denzin \& Lincoln serta pandangan Guba \& Lincoln yakni 1) penelitian dilakukan dengan kontek dan latar alamiah, 2) bertujuan untuk mendapatkan pemahaman mendalam atas fenomena, 3) keterlibatan mendalam antara peneliti dengan pihak yang diteliti, 4) cara mengumpulkan data tanpa adanya treatment atau manipulasi variabel, 5) teknik, konsep dan fokus untuk mengumpulkan data bersifat fleksibel, 6) hubungan antara peneliti dengan subyek penelitian mempengaruhi tingkat akurasi data, dan 7) adanya penggalian nilai budaya, sosial yang berdampak pada suatu perilaku (Herdinsyah, 2019).

Penelitian ini memfokuskan pada subyek pajak badan yang mempunyai kewajiban angsuran PPh pasal 25 dan memanfaatkan insentif pajak pada tahun pajak 2020 di KPP Pratama Medan Petisah. Lokasi penelitian ini dilakukan di kota Medan karena mempunyai Produk Domestik Regional Bruto (PDRB) di Sumatera Utara dan urutan kelima di Indonesia (Aditya, 2020). Dengan capaian PDRB yang tinggi menunjukkan tingginya pertumbuhan ekonomi dan bertambahnya subyek pajak badan di wilayah ini.

Proses penelitian meliputi mengidentifikasi masalah, mengumpulkan data, menentukan rumusan masalah penelitian, menyusun kerangka teori, desain penelitian, melakukan analisis dan pembahasan data hasil penelitian dan laporan (Sekaran, 2015).

Penelitian ini juga mengumpulkan data dari sumbernya (primer) dan data sekunder berupa:

a. Data primer

Pengumpulan data ini berasal dari subyek penelitian dengan melakukan wawancara kepada narasumber. Peneliti memutuskan pihak narasumber berdasarkan teknik purposive sampling, yaitu pegawai KPP yang menjabat sebagai Kepala Seksi, Account Representative (AR) dan Petugas Penyuluh Pajak di unit kerja KPP Pratama Medan Petisah.

b. Data sekunder

Pengumpulan data dilakukan dari pihak yang terlibat dalam pelaksanaan insentif pajak dan dari sumber tidak langsung berupa:

1) Dokumen arsip laporan realisasi penerimaan dan realisasi insentif pajak di KPP Pratama Medan Petisah dan;

2) Buku-buku, artikel ilmiah hasil penelitian, artikel di internet, dan peraturan perpajakan yang relevan dengan penelitian pelaksanaan insentif pajak.

Informasi dari hasil wawancara yang diperoleh dalam penelitian akan diklasifikasikan berdasarkan 
faktor yang berhubungan dengan penerapan kebijakan publik menurut teori G Edward III yaitu komunikasi, sumber daya, disposisi dan struktur birokrasi. Selain itu juga akan dijelaskan kendala dan upaya yang dilakukan dalam mendukung keberhasilan insentif pajak di KPP Pratama Medan Petisah.

\section{HASIL PENELITIAN}

4.1. Penerimaan Pajak KPP Pratama Medan Petisah Kantor Pelayanan Pajak (KPP) Pratama Medan Petisah mempunyai wilayah kerja di kota Medan. Tahun 2020, kota Medan mampu menempati urutan kelima Produk Domestik Regional Bruto (PDRB) di Indonesia, kondisi ini diharapkan dapat menambah penerimaan pajak. Dalam lima tahun terakhir jumlah wajib pajak (WP) badan yang terdaftar di KPP Pratama Medan Petisah meningkat 19,05\%, semula 13.108 menjadi 15.606 wajib pajak. Kondisi ini menunjukkan pertumbuhan kegiatan usaha yang berkontribusi menopang penerimaan pajak di KPP.

Kegiatan usaha dari wajib pajak terdaftar di KPP Pratama Medan Petisah sangat beragam namun tidak diketahui nilai potensi pajak secara pasti dan sampai dengan saat ini belum mencapai target penerimaan yang ditetapkan. Pada tahun 2020, capaian penerimaan pajak sebesar $86,24 \%$ dari target penerimaan.

Grafik 1. Jumlah WP Terdaftar KPP dari tahun 2016 s.d. 2020

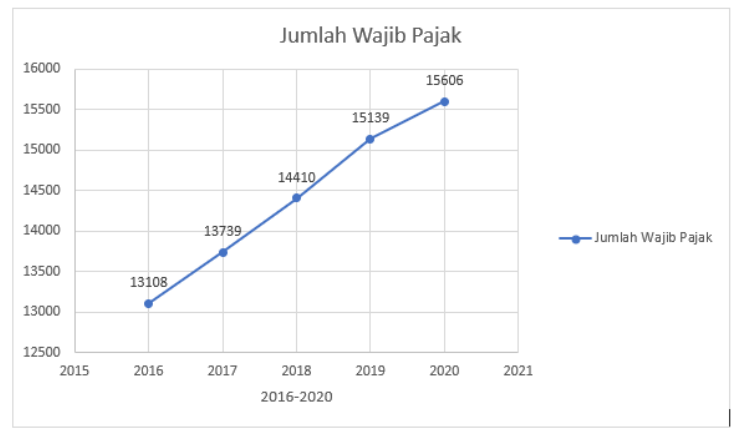

Sumber: Seksi PKD KPP Pratama Medan Petisah

Kondisi ini terjadi karena adanya penurunan perekonomian sebagai dampak dari pandemi covid-19. Selain itu penerimaan pajak belum optimal karena adanya perubahan tarif PPh badan, sebelumnya $25 \%$ turun menjadi $22 \%$.
Grafik 2. Target dan Realisasi Penerimaan KPP Pratama Medan Petisah

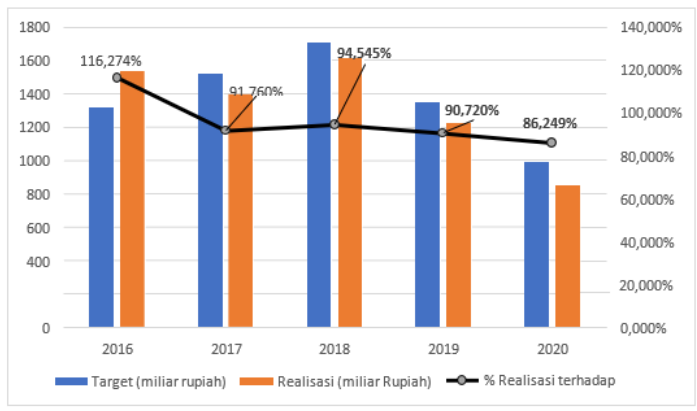

Sumber: Seksi PKD KPP Pratama Medan Petisah

Penurunan tarif PPh Badan memengaruhi nilai setoran PPh pasal 25 yang disetorkan wajib pajak badan berpedoman pada perhitungan angsuran PPh pasal 25 yang dilaporkan pada SPT Tahunan PPh.

Grafik 3. Angsuran PPh pasal 25 di tahun 2020

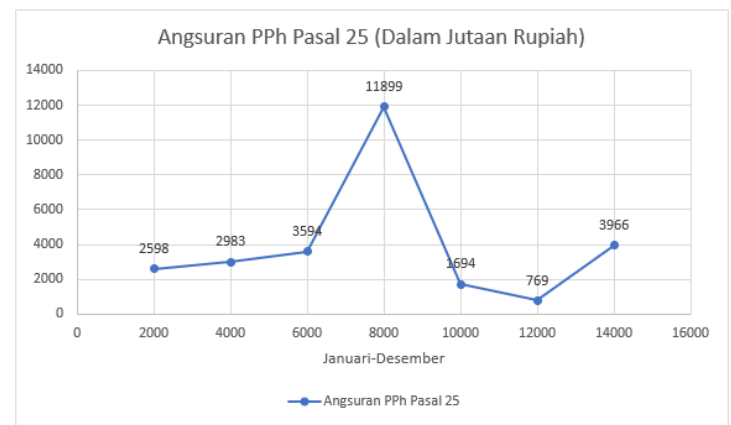

Sumber: Diolah dari Seksi PKD KPP Pratama Medan Petisah

Data penerimaan angsuran PPh pasal 25 di KPP Pratama Medan Petisah periode Januari sampai dengan Maret 2020 lebih tinggi dari bulan selanjutnya karena wajib pajak masih melakukan pembayaran angsuran berdasarkan angsuran Desember 2019. Penurunan penerimaan jenis pajak PPh pasal 25 disebabkan perubahan tarif PPh badan, semula $25 \%$ menjadi 22\%. Dengan demikian jumlah PPh terutang yang dibayar sendiri menjadi lebih kecil. Selanjutnya mulai masa pajak April 2020, jumlah angsuran PPh 25 meningkat 331\% sesuai hasil perhitungan SPT Tahunan PPh tahun pajak 2019. Namun sejak masa pajak Mei 2020, penerimaan pasal 25 mengalami penurunan hingga $85,76 \%$ karena kondisi pandemi dan wajib pajak mulai memanfaatkan insentif pajak yang diterbitkan pemerintah.

\subsection{Penerapan Insentif Pajak di KPP Pratama Medan Petisah}

Program Pemulihan Ekonomi Nasional (PEN) dicanangkan untuk upaya mendorong pertumbuhan ekonomi. Salah satu program PEN adalah insentif pajak kepada wajib pajak badan yang terdampak pandemi 
berupa pengurangan setoran PPh pasal 25 mulai masa pajak April 2020 s.d. bulan Desember 2020. Di KPP Pratama Medan Petisah program ini dilaksanakan dengan melakukan sosialisasi dan edukasi kepada wajib pajak. Insentif pajak berupa pengurangan angsuran PPh pasal 25 diberikan melalui permohonan oleh wajib pajak dan untuk tertib administrasi bagi wajib pajak akan diterbitkan surat persetujuan dan setiap bulannya wajib melaporkan realisasi melalui aplikasi www.pajak.go.id

Grafik 4. Data permohonan pengurangan angsuran PPh pasal 25 dibandingkan dengan jumlah WP yang wajib Angsuran PPh pasal 25

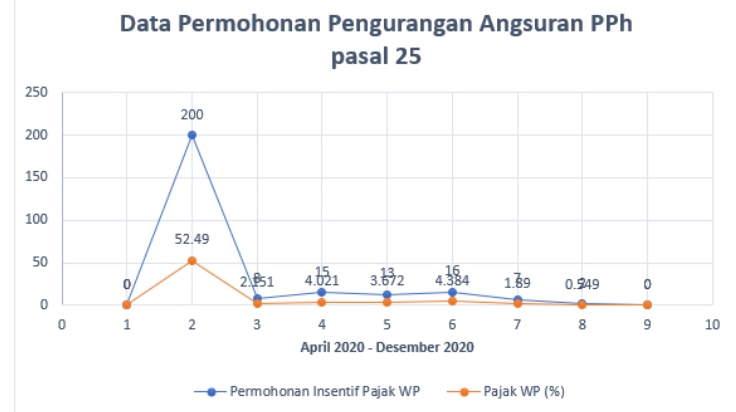

Sumber: Seksi PKD KPP Pratama Medan Petisah

Data perusahaan yang memanfaatkan insentif pajak di KPP Pratama Medan Petisah pada periode 1 Mei 2020 s.d. 31 Desember 2020 terus menurun dan nihil pada bulan Desember 2020. Penjelasan kepala seksi waskon dan AR menyatakan bahwa seluruh pelayanan insentif pajak dilakukan melalui aplikasi www.djponline.pajak.go.id, sehingga kurangnya pemahaman dan kemampuan wajib pajak di bidang teknologi serta dukungan jaringan internet menjadi kendala utama. Hal ini mengakibatkan proses administrasi insentif di aplikasi tidak dapat diselesaikan secara tuntas sehingga insentif pajak tidak dapat dimanfaatkan.

4.3. Kendala yang dihadapi dalam penerapan insentif pajak

Pajak merupakan kontribusi masyarakat kepada negara yang bersifat memaksa dan tidak menerima kontraprestasi langsung kepada pihak yang membayarnya. Kebijakan pajak sebagai bagian kebijakan publik tentunya banyak menghadapi kendala dalam implementasinya. Kepatuhan pajak di Indonesia belum optimal karena banyak faktor yang mempengaruhi antara lain sikap optimis wajib pajak, pengetahuan tax professional, kondisi keuangan perusahaan, faktor lingkungan dan moral dari tax professional (Aryati, 2016). Penelitian di kota Medan Belawan juga menemukan kualitas pelayanan dan sanksi perpajakan berpengaruh signifikan terhadap kepatuhan pajak (Arifin, 2017).

Demikian juga kebijakan insentif pajak yang menjadi salah satu program dalam PEN tahun 2020. Di KPP Pratama Medan Petisah, insentif pajak hanya dimanfaatkan oleh sebagian wajib pajak badan. Menurut keterangan petugas account representative (AR) terdapat kendala dalam penerapan insentif pajak khususnya pengurangan angsuran PPh pasal 25 . Kendala tersebut antara lain:

\subsubsection{Rendahnya penguasaan teknologi oleh wajib pajak}

Insentif pajak ditujukan kepada wajib pajak dengan Klasifikasi Lapangan Usaha (KLU) tertentu yang sudah dicantumkan pada Peraturan Menteri Keuangan. Wajib pajak dapat memanfaatkan Insentif pajak dengan menyampaikan surat permohonan ke kantor pajak dan melaporkan realisasi insentif setiap bulannya melalui aplikasi www.pajak.go.id. Hasil wawancara dengan petugas pajak, menyatakan meskipun aplikasi perpajakan yang disediakan Direktorat Jenderal Pajak (DJP) sudah sering digunakan oleh wajib pajak, namun dalam pengajuan insentif pajak masih terdapat kendala pada aplikasi www.pajak.go.id. Jadi kendala penggunaan teknologi ini menjadi penyebab rendahnya wajib pajak badan yang menyampaikan permohonan pengurangan setoran PPh pasal 25.

4.3.2. Prosedur administrasi insentif pajak yang dianggap rumit

Peraturan Menteri Keuangan Nomor PMK44/PMK.03/2020, PMK-86/PMK.03/2020 dan PMK110/PMK.03/2020 mengatur fasilitas insentif pajak berupa pengurangan setoran PPh pasal 25 dapat diajukan dengan surat permohonan tertulis kepada Kepala KPP di tempat wajib pajak badan terdaftar.

Setelah wajib pajak mendapat Surat Keterangan (Sket) yang menunjukkan persetujuan penurunan angsuran PPh pasal 25 maka setiap bulannya wajib melaporkan realisasi penurunan angsuran PPh pasal 25 melalui aplikasi www.pajak.go.id. Hasil wawancara kepada Account Representative (AR) menyatakan bahwa prosedur administrasi ini bagi wajib pajak masih sulit dipenuhi sehingga memilih tidak memanfaatkan insentif pajak dan tetap menyetor angsuran PPh pasal 25.

\subsubsection{Pola pikir wajib pajak tentang angsuran PPh pasal 25 \\ Pembayaran Angsuran PPh pasal 25 merupakan} pembayaran pajak tahun berjalan. Jumlah angsuran yang sudah disetorkan akan diperhitungkan dengan jumlah PPh terutang pada akhir tahun pajak. Apabila jumlah PPh terutang lebih besar dari pembayaran pajak tahun berjalan maka kekurangnnya wajib disetor sebelum SPT Tahunan disampaikan. Demikian juga 
sebaliknya apabila PPh terutang lebih kecil dibandingkan pembayaran pajak tahun berjalan maka kelebihan pajak akan dikembalikan melalui mekanisme pemeriksaan pajak.

Saat ini kewajiban pembayaran angsuran PPh 25 dilakukan dengan menyetorkan angsuran pajak ke bank persepsi dan secara otomatis setoran tersebut akan dicatat pada Modul Penerimaan Negara (MPN) yang terintegrasi dengan database di KPP. Dengan demikian tidak ada lagi prosedur administrasi yang wajib dilakukan oleh wajib pajak.

Pada masa pandemi, pemerintah menyadari bahwa pengurangan angsuran PPh pasal 25 dapat membantu aliran kas perusahaan. Sehingga kebijakan insentif pajak diterbitkan sejak adanya pandemi covid 19. Dalam upaya transparansi dan pertangungjawaban kebijakan insentif pajak, tentunya wajib pajak perlu melengkapi kelengkapan administrasi berupa surat permohonan dan pelaporan realisasi insentif pajak. Prosedur administrasi ini masih menjadi kendala bagi wajib pajak sehingga pemanfaatan insentif tidak dapat dilakukan secara optimal. Pola pikir masyarakat yang menginginkan insentif diberikan langsung tanpa kelengkapan administrasi tentunya sulit diwujudkan sehingga diperlukan sosialisasi dan edukasi mengenai pentingnya administrasi perpajakan dalam mewujudkan transparansi dan pertangungjawaban kebijakan perpajakan.

4.4. Mengukur keberhasilan implementasi insentif pajak dengan teori G Edward III

Menurut teori G Edwards III, capaian kebijakan publik dipengaruhi empat unsur yaitu komunikasi, sumber daya, disposisi serta struktur birokrasi. Keempat unsur saling berhubungan dan memengaruhi, untuk mencapai keberhasilan implementasi kebijakan publik. Faktor-faktor tersebut apabila dikaitkan dengan insentif pajak diperoleh hasil:

\subsubsection{Komunikasi}

G Edwards III berpendapat komunikasi atas kebijakan publik perlu diketahui dengan memahami tujuan dari keputusan kebijakan publik secara jelas dan benar, sehingga pelaku dapat menyiapkan dan memutuskan langkah alternatif secara konsisten untuk mewujudkan kebijakan publik tersebut. Kondisi pandemi covid 19 telah mengakibatkan turunnya perekonomian di berbagai sektor. Pemerintah mencanangkan program Pemulihan Ekonomi Nasional (PEN) dengan memberikan insentif pajak berupa pengurangan angsuran PPh pasal 25 bagi wajib pajak yang terdampak pandemi. Insentif pajak ini diberikan untuk membantu wajib pajak menjaga aliran kas perusahaan dan mampu bertahan pada masa pandemi. Data wajib pajak yang wajib menyetor angsuran PPh pasal 25 dan memenuhi syarat untuk mendapatkan insentif pajak dapat dilihat pada data grafik 5, sehingga implementasi insentif pajak dianggap berhasil apabila dimanfaatkan oleh seluruh wajib pajak yang memenuhi kriteria.

Grafik 5. Data wajib pajak yang menyetor PPh pasal 25 dan wajib pajak yang memanfaatkan insentif pajak pada tahun 2020

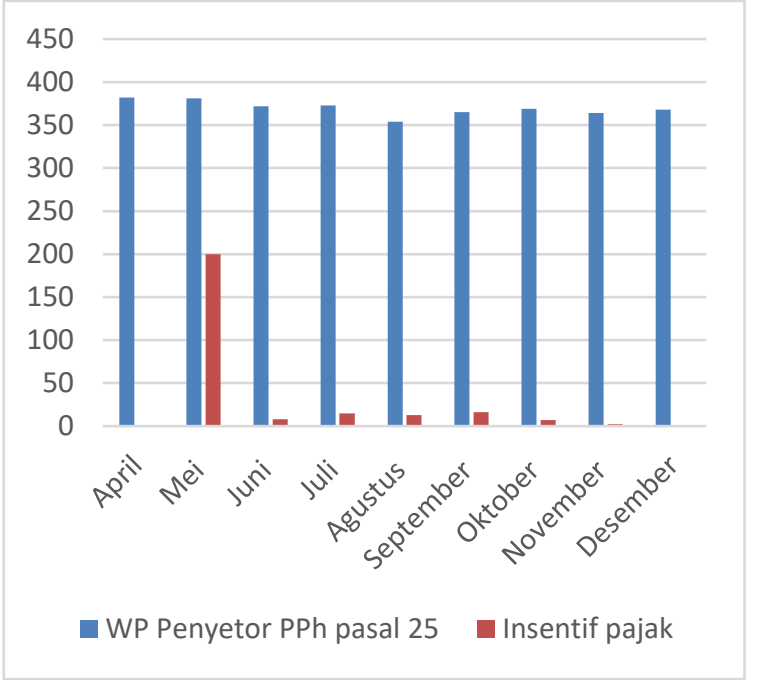

Sumber: Seksi PKD KPP Pratama Medan Petisah

Program insentif pajak telah disampaikan kepada wajib pajak melalui media sosial resmi KPP, melakukan sosialisasi dan menyelenggarakan kelas pajak secara terjadwal. Pada saat melakukan sosialisasi ini, telah disampaikan tujuan insentif pajak yaitu untuk membantu dan memudahkan wajib pajak menjaga likuiditas akibat kondisi usaha yang sedang turun.

Hasil wawancara dengan karyawan KPP Pratama Medan Petisah sebagai pelaksana kebijakan insentif pajak menjelaskan fasilitas pengurangan setoran PPh pasal 25 sudah diinformasikan melalui media internal berupa portal DJP, mengenalkan menu pada aplikasi www.pajak.go.id dan sosialisasi secara daring yang dilakukan kantor pusat DJP ke seluruh wilayah kerjanya.

Informasi terkait sosialisasi insentif pajak juga disampaikan AR dan kepala seksi pengawasan dan konsultasi (waskon) menyatakan, insentif pajak ini telah diinformasi kepada wajib pajak badan yang terdaftar di KPP melalui sosialisasi langsung, media sosial, webinar, bimbingan pada kelas pajak serta kegiatan Bussiness Development Service (BDS). Hal ini terbukti wajib pajak badan telah memahami adanya insentif pajak dan sebanyak 200 wajib pajak badan atau $52,49 \%$ dari wajib pajak terdaftar telah mengajukan permohonan untuk masa Mei 2020. Namun kondisi ini hanya berjalan satu bulan, karena wajib pajak yang berhak atas insentif pajak ini tidak melanjutkan dan memilih meyetor angsuran PPh pasal 25 sesuai hasil perhitungan SPT.

Pendapat berbeda disampaikan Asisten Penyuluh Pajak Terampil, menjelaskan bahwa penyampaian 
informasi insentif pajak telah dilakukan dengan berbagai media, namun sebagian wajib pajak belum mengerti secara lengkap prosedur untuk memanfaatkan insentif sehingga wajib pajak yang sudah mendapat persetujuan insentif pajak berupa surat keterangan tidak melanjutkan proses administrasi berupa laporan realisasi dan pemanfaatannya tidak berkelanjutan.

Jadi, berdasarkan faktor komunikasi penerapan kebijakan insentif pajak masih belum optimal karena masyarakat telah mengetahui adanya insentif pajak namun belum memahami dengan lengkap bagaimana prosedur yang benar untuk memperoleh insentif pajak tersebut. Hal ini ditunjukkan pada masa Mei 2020 terdapat 200 dari 381 wajib pajak atau 52,49\% dari wajib pajak mengajukan permohonan insentif pajak. Atas permohonan tersebut sudah mendapat persetujuan dari KPP, namun pada masa-masa berikutnya wajib pajak tidak mengisi aplikasi insentif pajak berupa data realisasi angsuran PPh pasal 25 yang diberikan insentif pajak. Kondisi ini mengakibatkan insentif pajak tidak memenuhi formal dan secara sistem dianggap wajib pajak tidak memanfaatkan insentif pajak.

\subsubsection{Sumber daya}

Faktor kedua keberhasilan pelaksanaan kebijakan publik adalah unsur sumber daya. Unsur sumber daya berperan untuk menyiapkan kelengkapan administrasi dan proses layanan untuk wajib pajak. Pegawai ditugaskan untuk memberikan pelayanan terkait insentif pajak pada seksi pengawasan dan seksi pelayanan sudah cukup untuk melayani permohonan insentif pajak. Pegawai yang ditugaskan mempunyai tingkat pendidikan yang memadai yaitu terendah diploma III perpajakan dan sudah mendapat pembekalan tentang insentif pajak.

Penjelasan AR dan petugas penyuluh pajak menyatakan permohonan penurunan angsuran PPh pasal 25 di masa pandemi semuanya dilaksanakan melalui aplikasi online melalui menu www.djp.online.go.id sehingga tidak ada tatap muka secara langsung dengan wajib pajak. Hambatan yang dihadapi wajib pajak berupa jaringan internet yang tidak stabil dan pemahaman atas menu pada aplikasi insentif pajak. Proses penyelesaian administrasi pada aplikasi online ini telah menggunakan perangkat keras dan lunak yang handal, tersedianya jaringan internet yang lancar dan seluruh pegawai sudah memahami aplikasi komputer sehingga pelayanan dapat diberikan secara maksimal. Kondisi ini didukung oleh kepala seksi waskon yang menyatakan terkait sumber daya berupa perangkat komputer, jaringan dianggap cukup memadai, walaupun terkadang terdapat kendala jaringan karena kondisi work from home (WFH) yang mewajibkan pegawai memberikan pelayanan dari rumah masing-masing.
Berdasarkan uraian di atas, dari faktor kesiapan sumber daya implementasi kebijakan insentif pajak telah terpenuhi yaitu seluruh permohonan telah diterbitkan persetujuan oleh KPP dengan tepat waktu dan seluruhnya diproses dengan lancar melalui aplikasi yang tersedia.

\subsubsection{Disposisi / Sikap Pelaksana}

Faktor disposisi merupakan faktor yang berpengaruh pada keberhasilan penerapan kebijakan insentif pajak. Fasilitas pengurangan angsuran PPh pasal 25, seluruh layanan dilakukan secara online sehingga wawancara langsung dengan wajib pajak yang memanfaatkan insentif ini belum dapat dilakukan. Wawancara terpisah dilakukan kepada WP di wilayah lain menyatakan insentif pajak berupa pengurangan angsuran sangat membantu dan prosedurnya sangat mudah. Kelengkapan administrasi fasilitas insentif pajak semuanya diselesaikan melalui aplikasi www.pajak.go.id tanpa bertemu dengan petugas pajak sehingga dapat disampaikan dari mana saja. Hambatan yang utama dialami wajib pajak adalah jaringan internet yang lambat dan tidak tersedianya perangkat komputer. Menurut penjelasan kepala seksi waskon dan AR, selama pelayanan insentif pajak secara umum wajib pajak menyatakan puas dengan insentif pajak, walaupun terdapat wajib pajak yang menyatakan kurang puas karena KLU yang tercantum pada database DJP tidak sesuai dengan kondisi usaha sebenarnya karena adanya kesalahan pada saat awal registrasi NPWP. Atas kondisi ini sudah diatasi dengan melakukan update profile wajib pajak.

Jadi, berkaitan dengan insentif pajak, faktor disposisi belum dapat diukur secara pasti dan sedikitnya minat wajib pajak untuk mengajukan insentif pajak sebagian besar disebabkan kendala jaringan internet dan administrasi insentif pajak yang harus dipenuhi pada menu aplikasi yang sudah disediakan pada aplikasi www.dip.online.go.id.

\subsubsection{Struktur birokrasi}

Faktor keempat yang berperan dalam keberhasilan kebijakan publik adalah struktur birokrasi. Dalam struktur birokrasi ini, kebijakan publik berupa insentif pajak ditekankan pada standard operating procedur (SOP) untuk proses permohonan insentif pajak. Penjelasan Kepala seksi waskon dan AR, menyatakan bahwa kebijakan insentif pajak sudah tersedia prosedur yang rinci dan jelas pada Peraturan Menteri Keuangan (PMK) dan peraturan Dirjen pajak mengenai syarat insentif pajak dan proses tindak lanjut yang dilakukan oleh petugas pajak (DJP). Pemberian insentif pajak dimulai pada saat permohonan disampaikan oleh wajib pajak melalui menu aplikasi www.pajak.go.id. Permohonan yang diterima KPP akan dilakukan penelitian atas persyaratan untuk mengetahui Klasifikasi Lapangan Usaha (KLU) wajib 
pajak dan bagi wajib pajak yang memenuhi kriteria akan diterbitkan surat keterangan (Sket) dan secara langsung setoran PPh pasal 25 akan berkurang sebesar $50 \%$ dari nilai sebelumnya.

Bagi wajib pajak yang sudah mendapat persetujuan, maka angsuran PPh 25 yang baru wajib dilaporkan sebagai realisasi setiap bulan melalui aplikasi www.pajak.go.id yaitu data setoran PPh 25 yang disetorkan dan secara otomatis akan dikurangkan sebesar 50\%. Realisasi atas insentif PPh pasal 25 ini wajib dilaporkan setiap bulannya paling lambat pada tanggal 20 bulan berikutnya dari masa pajak yang menerima pengurangan pajak.

Berdasarkan keadaan di atas, unsur struktur birokrasi dalam pelaksanaan insentif pajak sudah terpenuhi karena adanya SOP yang secara rinci pada menu aplikasi secara online yang dapat memandu wajib pajak sehingga sangat mudah dalam memanfaatkan insentif pajak.

Berdasarkan uraian di atas berupa hasil wawancara dan pengamatan di lapangan, pelaksanaan insentif pajak di KPP Pratama Medan Petisah, telah memenuhi faktor keberhasilan yang dicetus oleh $\mathrm{G}$ Edward III yaitu komunikasi, sumber daya, sikap pelaksana dan struktur birokrasi. Namun dalam penerapan unsur komunikasi belum efektif sehingga insentif pajak belum berhasil dimanfaatkan secara optimal oleh wajib pajak. Selain itu suatu kebijakan publik akan mencapai tujuan yang optimal karena dipengaruhi banyak variabel yang bersifat individu maupun kelompok (Subarsono, 2020). Khususnya pengurangan angsuran PPh pasal 25 ini tidak banyak dimanfaatkan oleh wajib pajak karena faktor lain misalnya pengurangan ini bersifat sementara karena angsuran PPh pasal 25 hanya merupakan uang muka pajak dan wajib pajak tetap akan melunasi jumlah pajak terutang di akhir tahun.

\section{KESIMPULAN DAN SARAN}

\subsection{Kesimpulan}

Berdasarkan pembahasan di atas, dapat disimpulkan sebagai berikut. Pertama, Teori G Edward III dalam implementasi pengurangan angsuran PPh pasal 25 di KPP Pratama Medan Petisah belum dimanfaatkan secara optimal. Hal ini disebabkan faktor komunikasi dan disposisi yang belum efektif. Wajib Pajak sudah memahami adanya insentif pajak namun belum paham prosedur mendapatkan insentif secara menyeluruh. Untuk faktor lainnya berupa sumber daya dan struktur birokrasi telah dipenuhi dalam penerapan insentif pajak ini. Kedua,terdapat kendala dalam implementasi kebijakan insentif pajak ini berupa: (a) Penguasaan teknologi yang tidak merata sehingga layanan melalui aplikasi online tidak mampu dilakukan oleh sebagian wajib pajak, (b) administrasi berupa penyampaian realisasi insentif pajak setiap bulan bagi wajib pajak yang mendapat persetujuan, dianggap rumit, dan (c) pola pikir keliru dari wajib pajak yang berpendapat insentif pajak menimbulkan kewajiban pajak pada periode berikutnya.

\subsection{Saran}

Pertama, kebijakan pajak yang diterapkan oleh DJP perlu memilih media komunikasi yang tepat sesuai karakteristik wilayah kerja DJP. Misalnya sosialisasi, pendampingan atau kelas pajak. Kedua, pemanfaatan fasilitas insentif pajak dapat disampaikan dengan pilihan menu administrasi administrasi yang dipilih wajib pajak sesuai keadaan wajib pajak. Contohnya terdapat pilihan layanan insentif pajak yang diajukan melalui aplikasi online atau permohonan manual untuk wajib pajak tertentu.

\section{KETERBATASAN}

Penelitian ini telah dilakukan dengan prosedur ilmiah, namun masih terdapat keterbatasan meliputi: (a) obyek penelitian hanya terbatas pada KPP Pratama Medan Petisah sehingga hasil penelitian ini belum dapat menggambarkan pelaksanaan kebijakan publik secara menyeluruh, (b) penelitian yang dilakukan dengan metode kualitatif sehingga wawancara mendapam perlu dilakukan. Namun dengan pertimbangan waktu dan kondisi pandemi, peneliti hanya dapat melakukan wawancara secara daring sehingga informasi yang diperoleh tidak optimal, dan (c) peneliti hanya melakukan wawancara kepada sebagian pegawai DJP yang terlibat dalam pelaksanaan insentif pajak di KPP yaitu kepala seksi, account representatif (AR) dan fungsional penyuluh sehingga masih dimungkinkan terdapat informasi yang belum terungkap.

\section{DAFTAR PUSTAKA}

Aditya. (2020). 10 Wilayah dengan Skala Ekonomi Terbesar di Indonesia. Jakarta. Retrieved from https://www.goodnewsfromindonesia.id/202 0/10/17/inilah-kabupaten- kota-denganskala-ekonomi-terbesar-di-indonesia

Ahmar, N. (2018). Model Kebijakan Ekonomi Berbasis Insentif Pajak Revaluasi Aset Sebagai Potensi Penerimaan Pajak. Simposium Nasional Keuangan Negara, 41-57.

Ahmar, N., Usman, M.N., \& Pujiati, D (2018). Kebijakan Ekonomi Berbasis Insentif Pajak Revaluasi Aset untuk Meningkatkan Penerimaan Pajak.

Arifani, M. R. (2021). Implementasi Insentif Pajak di KPP Pratama Pontianak Timur. Jurnal Pajak Indonesia (Indonesian Tax Review), 5(2), 164173.

Arifin, S. B. (2017). Pengaruh Kualitas Pelayanan dan Sanksi Perpajakan Terhadap kepatuhan Wajib Pajak Badan di KPP Pratama Medan belawan. Jurnal Akuntansi Dan Bisnis: Jurnal Program Studi Akuntansi, 3(2), 177-186. 
Aryati, T. (2016). Analisis faktor-faktor yang mempengaruhi tingkat kepatuhan Wajib Pajak Badan. Media Ekonomi dan Manajemen, 25(1), 13-29.

Asrul, A. L. (2018). Analisis Faktor-Faktor Yang Mempengaruhi Manajemen Perusahaan Mengikuti Tax Amnesty. PARADOKS: Jurnal Ilmu Ekonomi, 1(1), 132-151.

Atikasari, T. T. (2017). Dampak Revaluasi Aset Tetap Terhadap Pajak Penghasilan Yang Terhutang. Jurnal IImu dan Riset Akuntansi (JIRA), 6(8), 115.

BPS, B. P. (2020). Produk Domestik Regional Bruto Per Kapita menurut Kbupaten atas Dasar Harga Konstan 2010. Retrieved from https://sumut.bps.go.id/statictable/2020/06/ 06/1796/produk- domestik-regional-brutoper-kapita-menurut-kabupaten-kota-atasdasar- harga-konstan-2010-rupiah-2017--2019.html

Budiman, N. A. (2020). Dampak Covid-19 dan Pemanfaatan Insentif Pajak terhadap Keberlangsungan Usaha pada UMKM Tenun Troso Jepara. Jurnal Manajemen dan Keuangan, 276-285.

Butar, S. B. (2019). Analisis Kritis Atas Kebijakan Revaluasi Aset Kementerian Keuangan Tahun 2015. Praxis: Jurnal Sains, Teknologi, Masyarakat dan Jejaring, 164-184.

Easson, A. \&. (2002). Tax incentives. World Bank Instutute.

Fauzia, M. (2020). Indonesia Resmi Resesi, Ekonomi Kuartal III-2020 Minus 3,49 Persen. Kompas. Retrieved from https://money.kompas.com/read/2020/11/0 5/111828826/indonesia-resmi- resesiekonomi-kuartal-iii-2020-minus-349persen?page=all\#: :text=What

Hafidiah, A. \&. (2021). Implementasi Angsuran PPH Pasal 25 CV RM Sebagai Wajib Pajak Terdampak Pandemi Corona Virus Disease 19. Jurnal Indonesia Sosial Sains, 09-18.

Hani, S. \& Daoed, H.R. (2013). Analisis Penurunan Tarif PPh Badan dalam Meningkatkan Penerimaan PPh di KPP Pratama Medan Barat. Jurnal Riset Akuntansi dan Bisnis, 13(1), 55-79.

Herdinsyah, H. (2019). Metodelogi Penelitian Kualitati. Jakarta: Salemba Humanika.

Indrawati. (2018). Metode Penelitian Qualitatif. Bandung: PT Refika Aditama.

Kartikaningdyah, E. \&. (2018). Pengaruh Persepsi Tax Amnesty Dan Pengetahuan Wajib Pajak Badan Terkait UU No 11 Tahun 2016 Terhadap Kepatuhan Wajib Pajak Badan. Jurnal Akuntansi, Ekonomi Dan Manajemen Bisnis, 201-212.

Kartiko, N. D. (2020). Insentif pajak dalam merespons dampak pandemi covid-19 pada sektor pariwisata. JURNAL PKN (Jurnal Pajak dan Keuangan Negara), 124-137.

Khairiyah, Y. R. (2019). Studi Kualitatif: Dampak Kebijakan Insentif Pajak Usaha Kecil dan Menengah Terhadap Kepatuhan Pajak dan Penerimaan Negara. Jurnal Manajemen Keuangan Publik, 36-45.

Laksmi, D. N. (2016). Kontribusi Komponen Pendapatan Asli Daerah (PAD) terhadap Realisasi PAD Tahun Anggaran 2006-2015 Kota Magelang.

Latief, S. Z. (2020). Pengaruh Kepercayaan Kepada Pemerintah, Kebijakan Insentif Pajak dan Manfaat Pajak Terhadap Kepatuhan Wajib Pajak. Latief, S., Zakaria, J., \& Mapparenta, M. (2020). Pengaruh Kepercayaan Kepada Pemerintah, Kebijakan Insentif Pajak dan Manfaat Pajak Terhadap Kepatuhan Wajib Pajak. CESJ: Center of Economic Students Journal, 270-289.

Moleong, J. L. (2017). Metode Penelitian Kualitatif. Bandung: PT. Remaja Rosdakarya.

Muawanah \& Kurniawan. (2018). Analisis revaluasi aset berbasis perpajakan terhadap nilai perusahaan. Jurnal Sosial Ekonomi dan Humaniora (JSEH), 4(2), 71-82.

Murweni, I. (2018). Pelaksanaan Program Tax Amnesty Dalam Rangka Meningkatkan Kepatuhan Wajib Pajak Badan. Jurnal E-Bis (EkonomiBisnis), 56-63.

Putra, V. P. (2014). Insentif Keputusan Revaluasi Aset Tetap (Studi Empiris pada Perusahaan yang Terdaftar di Bursa Efek Indonesia).

Rachmawati, N. A. (2016). Manfaat Pemberian Insentif Pajak Penghasilan dalam Kepatuhan Wajib Pajak UMKM. Jurnal Akuntansi, Ekonomi dan Manajemen Bisnis, 176-185.

Rosdiana, R. T. (2005). Perpajakan Teori dan Aplikasi. Jakarta: PT Raja Grafindo Persada.

S, E. A. (2015). Implementasi Kebijakan Publik. Yogyakarta: Penerbit Gava Media.

Sari, R. (2018). Kebijakan Insentif Pajak Bagi Usaha Mikro Kecil dan Menengah. Info Singkat, 10(12), 19-24.

Sekaran, U. (2015). Metodologi Penelitian Untuk Bisnis. Jakarta: Salemba Empat.

Setiabudi, A. W. (2019). Analisis Pemenuhan Konsep Current Payment dan Final Liability Dalam Penghitungan PPh Pasal 25 dan Pengenaan Sanksi Terkait. Jurnal Akuntansi, 72-104.

Setyawan, D. \&. (2016). Analisis Implementasi Kebijakan Undang-Undang Desa Dengan Model Edward III Di Desa Landungsari Kabupaten Malang . Reformasi, 6(2), 125-133.

Sitohang A., \& Sinabutar, R. (2020). Analisis Kebijakan Insentif Pajak Di Tengah Wabah Covid-19 Di Indonesia. Jurnal Ekonomis, 13(3), 14-25. 
Sinulingga, L. O. (2018). Implementasi Kebijakan Pajak Progresif Bagi Kendaraan Bermotor. Perspektif, 7(1), 19-23.

Subarsono. (2020). Analisis Kebijakan Publik, Konsep, Teori dan Aplikasi. Yogyakarta: Pustaka Pelajar.

Suratno, S. A. (2020). Pengembangan Model Efektifitas Kebijakan Ekonomi Berbasis Tax Amnesty untuk Meningkatkan Kepatuhan Wajib Pajak di Indonesia. Jurnal Riset Akuntansi \& Perpajakan (JRAP), 274-254.

Utara, B. P. (2020). PDRB Kota Medan Atas Dasar Harga Berlaku Menurut Lapangan Usaha (Juta Rupiah), 2018-2020. Diambil kembali dari Badan Pusat Statistik :. Retrieved from https://medankota.bps.go.id/indicator/52/50 /1/-seri-2010-pdrb-kota- medan-atas-dasarharga-berlaku-menurut-lapangan-usaha.html

Widyaningtyas, N. S. (2020). Hubungan Antara Perilaku Wajib Pajak Dan Kebijakan Pajak Berdasarkan Sudut Pandang Behavioral Accounting. . EJurnal Akuntansi, , 30(1), 14-27.

Winarno, B. (2014). Kebijakan Publik (Teori, Proses dan Studi Kasus).

Wulan, R. S. (2015). Implementasi Pemungutan Pajak Bumi Dan Bangunan Perdesaan Dan Perkotaan (Pbb-P2) Di Dinas Pendapatan Dan Pengelolaan Keuangan Kota Surabaya. Publika, 3(4).

\section{DOKUMEN-DOKUMEN}

Kementerian Keuangan. (2018). Peraturan Kementerian Keuangan (PMK) Nomor 9/PMK.03/2018 tentang Perubahan Atas Peraturan Menteri Keuangan Nomor 243/PMK.03/2014 Tentang Surat Pemberitahuan (SPT).

Kementerian Keuangan. (2018). Peraturan Menteri Keuangan Nomor 215/PMK.03/2018 tentang Penghitungan Angsuran Pajak Penghasilan Dalam Tahun Pajak Berjalan Yang Harus Dibayar Sendiri Oleh Wajib Pajak Baru, Bank, Badan Usaha Milik Negara, Badan Usaha Milik Daerah, Wajib Pajak Masuk Bursa.
Kementerian Keuangan. (2019). APBN KITA (Kinerja dan Fakta).

Kementerian Keuangan. (2020). Peraturan Menteri Keuangan Nomor 44/PMK.03/2020 tentang Insentif Pajak untuk Wajib Pajak Terdampak Pandemi Corona Virus Disease 2019.

Kementerian Keuangan. (2020). Peraturan Menteri Keuangan No. 86/ PMK. 03/ 2020 tentang Insentif Pajak Untuk Wajib Pajak Terdampak Pandemi Corona Virus Disease 2019.

Kementerian Keuangan. (2021). Informasi APBN 2021 Percepatan Pemulihan Ekonomi dan Penguatan Reformasi.

Kementerian Keuangan. (2020). Peraturan Menteri Keuangan Nomor 110/PMK.03/2020 tentang Perubahan atas Peraturan Menteri Keuangan Nomor 86/PMK.03/2020 tentang Insentif Pajak bagi Wajib Pajak terdampak Pandemi Corona Virus Disease 2019.

Republik Indonesia. (2007). Undang-Undang No. 28 Tahun 2007 tentang Perubahan Ketiga Atas Undang-Undang Nomor 6 Tahun 1983 Tentang Ketentuan Umum dan Tata Cara Perpajakan.

Republik Indonesia. (2008). Undang-Undang No. 36 Tahun 2008 tentang Perubahan Keempat Atas Undang-Undang Nomor 7 Tahun 1983 Tentang Pajak Penghasilan. Jakarta: Sekretariat Negara.

Republik Indonesia. (2020). Peraturan Pemerintah Nomor 30 Tahun 2020 tentang Penurunan Tarif Pajak Penghasilan bagi Wajib Pajak Badan Dalam Negeri yang Berbentuk Perseroan Terbuka.

Republik Indonesia. (2020). Peraturan Pemerintah Pengganti Undang-Undang Nomor 1 Tahun 2020 tentang Kebijakan Keuangan Negara dan Stabilitas Sistem Keuangan untuk Penanganan Pandemi Corona Virus Disease 2019 (COVID-19) dan/atau dalam Rangka Menghadapi Ancaman yang Membahayakan. 